\title{
Pitkospuut vai laajentuva kenttä?
}

\author{
Insinööri- ja maisemasuunnittelu taidehistorian \\ kaanonin koetinkivinä
}

Maunu Häyrynen \& Linda Leskinen

doi.org/10.23995/tht.112149

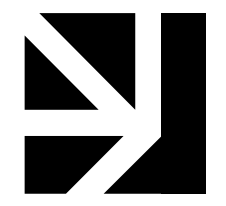

Artikkeli tarkastelee insinöörisuunnittelua sekä puutarha- ja maisemasuunnittelua suomalaisen taidehistorian marginaaleissa. Näin selvitetään, mitä niiden asemointi tutkimuksen kenttään kertoo alan institutionaalisista rajoista. Taidehistorian tutkimusalue määritellään nykyisin laajasti sekä taiteellisia että muita ilmiöitä käsittäväksi. Artikkelissa kuitenkin pohdimme, onko hierarkkinen jako taiteeseen ja ei-taiteeseen silti edelleen voimassa. Taide tutkimuskohteena määrittelee yhä tieteenalan identiteettiä ja jäsentyy edelleen kaanoneina. Vaikka niin puutarha- ja maisemasuunnittelu kuin insinöörisuunnittelu on kelpuutettu kotimaisen taidehistorian tutkimuskohteiksi, sen piirissä ylläpidetään näiden alojen ja arkkitehtuurin välistä erottelua. Tarkastelu osoittaa alan kaksijakoisen suhteen muihin kuin taiteellisiin tutkimuskohteisiin. Ne voidaan hyväksyä, mutta niiden näkyvyys taiteen kaanoniin yhä perustuvissa alan yleisteoksissa tai opetussisällöissä on satunnaista.

Asiasanat: insinöörisuunnittelu, maisemasuunnittelu, puutarha-arkkitehtuuri, maisemaarkkitehtuuri, puutarhataide, kaanon, taidehistoriallinen tutkimus 
Kirjoittaessaan vuonna 2005 taidehistorian ja visuaalisen kulttuurin tutkimuksen suhteesta Mieke Bal kehotti tutkimaan näiden rajoja niiden partioinnin sijaan ${ }^{1}$. Kehotus toimii tämän artikkelin lähtökohtana. Haluamme tarkastella insinöörisuunnittelua ja puutarha- tai maisemasuunnittelua taidehistorian piiriin kuuluvina, mutta ei sen ydinalueeseen lukeutuvina ilmiöinä ja pohtia, mitä näiden tutkimiemme alueiden asemointi suhteessa taidehistoriaan kertoo taidehistoriasta alana. Emme tavoittele insinöörisuunnittelun tai puistosuunnittelun uudelleenmäärittelyä taiteeksi vaan haluamme pohtia, miksi jokin tietty ilmiö taidehistorian kentässä määrittyy yksiselitteisesti taiteeksi, kun taas toinen samantapainen ilmiö ei - ja mitä seurauksia tällä voi olla sekä tutkittavan ilmiön että sen tutkimisen kannalta. Tämän pohjalta kysymme, onko jaottelu taiteeseen ja eitaiteeseen välttämätön, mielekäs tai toimiva tapa rajata taidehistorian, tässä tapauksessa erityisesti arkkitehtuurihistorian, tutkimusalue.

Taidemäärittelyt seuraavat tavalla tai toisella taidehistorian varjona silloinkin, kun ei tarkalleen ottaen olla tutkimassa taidetta. Vaikka taidehistorian tieteenalamäärittelyt voivat olla hyvinkin sisäänsulkevia ja monimuotoisuutta tukevia, James Elkins on kuvannut, miten käytännön määrittelyissä - kuten alan yleisteoksissa tai opetusohjelmissa - palataan kerran toisensa jälkeen taiteen kaanoneihin, niiden ja ei-taiteen rajanvetoon sekä taiteenalojen keskinäiseen hierarkiaan ja tiettyihin maantieteellisiin painotuksiin. ${ }^{2}$ Tähän taidehistorian kaksijakoisuuteen on kiinnittänyt huomiota myös Donald Preziosi, joka on Elkinsin tavoin nähnyt taidehistorian laajana kokoelmana tutkimusotteita, instituutioita, järjestelmiä ja toimintatapoja. Taidehistorian perusoletuksena on Preziosin mukaan kuitenkin sen tutkimien ilmiöiden välittämä taiteelliseen intentioon palautuva informaatio, jonka perus-

$1 \quad$ Mieke Bal, "The Commitment to Look," Journal of Visual Culture 4, no. 2 (2005): 22.

2 James Elkins, Stories of Art (New York \& London: Routledge, 2002), 55, 63-65, 85-87. teella ne sijoittuvat yhtenäiseen tila-aikamatriisiin teoksina. ${ }^{3}$ Taidehistoriallisen tutkimuksen lähtökohtia on kyseenalaistettu muun muassa sen ja visuaalisen kulttuurin tutkimuksen välisessä rajankäynnissä, missä jälkimmäinen voidaan määritellä sekä taidehistoriasta erillisenä että tähän kytkeytyvänä. ${ }^{4}$ Stephen Melville palauttaa visuaalisen kulttuurin Heinrich Wölfflinin primitiivin käsitteeseen. Hänen mielestään visuaalinen kulttuuri säilyttää luonteensa ikään kuin näkymättömänä varantona, josta toisinaan nostetaan jotain taiteen ja taidehistorian jalustalle. Pyrkiessään legitimoimaan visuaalisen kulttuurin ilmiöitä taidehistorian tutkimuskontekstissa tutkija tulee ikään kuin hyvää hyvyyttään vahvistaneeksi niiden poikkeavuutta, primitiivisyyttä. ${ }^{5}$

Taidehistorian suhteesta taiteen kaanoneihin on käyty keskustelua viime vuosikymmeninä. Kaanonit eivät liity vain taidehistoriaan, sillä myös muilla tieteenaloilla ja monissa muissakin sosiaalisissa konteksteissa esiintyy keskeisiksi tunnustettujen tekstien tai objektien joukkoja, joihin ryhmän keskuudessa yleisesti viitataan ja jotka

Donald Preziosi, Rethinking Art History. Meditations on a Coy Science (New Haven \& London: Yale University Press, 1989), 28-29, 34-36, 45-46; Donald Preziosi, "Art History: Making the Visible Legible," in The Art of Art History: A Critical Anthology, ed. Donald Preziosi (Oxford: Oxford University Press, 1998), 13-16.

4 Annamari Vänskä, Vikuroivia vilkaisuja. Ruumis, sukupuoli, seksuaalisuus ja visuaalisen kulttuurin tutkimus (Helsinki: Taidehistorian Seura, 2006), 22-30; Kuvasta tilaan. Taidehistoria tänään, toim. Kirsi Saarikangas (Tampere: Vastapaino, 1999), 8.

$5 \quad$ "You might then feel that it would be better to renew your objection, finesse Wölfflin's terms, and take aim at this primitive directly, or at least to admit that the region of active Wölfflinian principles is always only a local movement within a broader cultural field not governed by them. But of course there's a difficulty here: the primitive as such, visual culture taken as directly available, is invisible, disappearing into culture tout court and reappearing only when pulled out of that embeddedness by the workings of some larger history of vision (we construct visual culture out of a problem we must already have with 'art')." Stephen Melville, "'Theory', Discipline, and Institution," in Art History, Aesthetics, Visual Studies, ed. Michael Ann Holly \& Keith Moxey (New Haven, Conn.: Yale University Press, 2002), 203-214, 204. 
siten tuottavat ja vakauttavat sen identiteettiä. Kaanonin ulkopuolelle rajautuu aina asioita ja siihen muodostuu sisäisiä hierarkkisia jakoja. Tämä ei silti merkitse kaanonin lukittumista tiettyyn järjestykseen tai sen rajojen pysyvyyttä. Taidehistorian kaanonin voi tätä nykyä sanoa koostuvan potentiaalisesti hyvin moninaisista aineksista ja perustuvan myös muiden tieteenalojen tuottamaan tietoon. Näiden pohjalta se uudistuu jatkuvasti. Kaanoneita on käytännössä useita rinnakkain: "maailmantaiteen" ohella alueellisia ja kansallisia sekä eri taiteenaloja tai erilaisia ryhmiä koskevia. ${ }^{6}$

Nykytaidehistoriassa kaanoneihin pyritään ottamaan etäisyyttä. Perinteinen länsimainen ja patriarkaalinen taidekaanon ei enää ohjaa, eikä rajoita taidehistorian tutkimusta, eikä yhtenäistä tieteenalanäkökulmaa tai metodiikkaa enää entiseen tapaan löydy. ${ }^{7}$ Toisaalta tutkimuskohteen asemointi taiteeksi tai sen suhteuttaminen taiteeseen on edelleen osa taidehistorian tieteenalaidentiteettiä. Juuri taide tutkimuskohteena on erottanut taidehistoriaa muista historiaa tutkivista aloista ja kaanoneita kritisoineetkin taidehistorioitsijat ovat harvoin irtisanoutuneet kokonaan tästä rajauksesta. ${ }^{8}$

Asetelma muuttuu toisenlaiseksi, kun taidehistorioitsija saa tehtäväkseen koota yleistajuisen esityksen tai johdantokurssin kansallisesta tai kansainvälisestä taidehistoriasta tai kun taidehistoriallisen koulutuksen saanut tai alan tietoa hyödyntävä rakennussuojeluviranomainen inventoi tai laatii suojelulausuntoa. Jonkinlainen kaanon otetaan tällöin herkästi käyttöön taiteen kenttää jäsentävänä ja taidehistoriallista arvoa peruste-

6 Hubert Locher, "The idea of the canon and canon formation in art history," in Art History and Visual Studies in Europe: Transnational Discourses and National Frameworks, ed. M. Rampley et al. (Amsterdam: Brill, 2012), 31-33.

7 Selma Kraft, "Interdisciplinarity and the Canon of Art History," Issues in Integrative Studies, vol. 7 (1989): 57-71.

8 Locher, "The idea of the canon and canon formation," 37-40. levana rakenteena. Kaanonin muodostumiseen voivat vaikuttaa uudet tutkimusteemat ja tieteenalan kriittiset keskustelut, mutta lopputuloksessa voidaan yhä tunnistaa kaanonin piirteet: valitun rajauksen piirissä taiteeksi määritellyn kentän diakroninen kehityskaari, joka konkretisoituu tekijöiden ja teosten luettelona. Muutokset näkyvät kaanonin monipuolistumisena, kuten uusien ryhmien, taidemuotojen tai maantieteellisten alueiden sisällyttämisenä, mutta eivät kumoa kaanonin hierarkiaa. ${ }^{9}$ Yleisesitysten, opetusohjelmien tai suojeluluetteloiden valinnat eivät määrittele taidehistorian tieteellistä suuntaa, mutta ovat silti kiinteä osa sen institutionaalista kenttää.

Suomalaisen taidehistorian tutkimusalue ei rajaudu kansallisesti, mutta sen piirissä tuotetut kaanonit ovat enimmäkseen olleet kansallisia. Tässä artikkelissa tarkastellaan kahta aluetta, joita esimerkiksi väitöskirjatutkimukset ovat eriasteisesti legitimoineet osaksi taidehistorian kenttää: Puistojen ja puutarhojen suunnittelua on käsitelty Maunu Häyrysen ja Julia Donnerin taidehistorian väitöskirjoissa ${ }^{10}$, ja insinöörisuunnittelu on aiheena Linda Leskisen väitöstutkimuksessa. ${ }^{11}$ Näitä alueita on satunnaisesti sivuttu myös taidehistorian yleisesityksissä. ${ }^{12}$ Niiden ja taidehistorian välisen suhteen tarkastelu kertoo, miten tutkittavat ilmiöt sijoittuvat osaksi taidehistorian laajempaa kenttää ja miten ne paikantuvat suhteessa taidemäärittelyihin. Tarkaste-

9 Gregor Langfeld, "The canon in art history: concepts and approaches," Journal of Art Historiography 19, no. 12 (2018): 1-18; Meltem Gürel \& Kathryn Anthony, "The Canon and the Void: Gender, Race, and Architectural History Texts," Journal of Architectural Education 59, no. 3 (2006): 66-76.

10 Maunu Häyrynen, Maisemapuistosta reformipuistoon Helsingin kaupunkipuistot ja puistopolitiikka 1880-luvulta 1930-luvulle (Helsinki: Helsinki-Seura, 1994); Julia Donner, Kasvitarhasta puutarhakotiin. Naiset kotipuutarhan tekijöinä Suomessa 1870-1930 (Helsinki: Helsingin yliopisto, 2015).

11 Linda Leskinen, "Suomen kaunein tie. Tarvon moottoritie ja uuden kaupunkitilan rakentaminen 1956-1962 (työnimi)" (Väitöstutkimus, Helsingin yliopisto, tulossa).

12 Riitta Hurme et al., toim., Betoni Suomessa 1860-1960 (Helsinki: Suomen Betoniyhdistys, 1991). 
lulla pyrimme tekemään näkyviksi suomalaisen taidehistorian kaanonia tuottavia ja ylläpitäviä mekanismeja. ${ }^{13}$

\section{Kaksi näkymää taidehistorian laitamille}

Molemmat tarkasteltavat alueet suhteutuvat arkkitehtuuriin. Puutarhan asema on perinteisesti häilynyt arkkitehtuurin, puutarhauksen ja harrastuksen välillä yltäen joissakin historiallisissa konteksteissa yleisemmin tunnustetun taidemuodon asemaan, parhaiten tunnettuina esimerkkeinä 1600-luvun jardin à la française ja 1700-luvun englantilainen maisemapuutarha. 1800-luvulla alkanut kaupunkipuistojen suunnittelu on kehittynyt yhteydessä moderniin kaupunkisuunnitteluun ja monet arkkitehdit ovat myös suunnitelleet kaupunkipuistoja. Puutarhasuunnittelulle on yritetty vaihtelevalla menestyksellä luoda omaa kansainvälistä kaanoniaan, jonka rakennusosina ovat olleet edellä kuvatut paradigmaattiset esimerkit täydennettyinä muiden maiden kansallisilla puutarhatyyleillä, modernilla puistosuunnittelulla ja maisemaarkkitehtuurilla jne. ${ }^{14}$ Arkkitehtuurihistorian yleisesityksissä viitataan yleensä harvoihin yksittäisiin puutarhakohteisiin tai -suunnittelijoihin - tyypillisesti Versaillesin, Ryōanjin tai Stourheadin puutarhoihin, New Yorkin Central Parkiin sekä suunnittelijoista André Le Nôtreen, Capability Browniin tai kaupunkipuistojen osalta Robert Paxtoniin ja Frederick Law Olmst-

13 Vrt. Langfeld, "The canon in art history," 14; Locher, "The idea of the canon and canon formation," 40.

14 Marie Luise Gothein, Geschichte der Gartenkunst I-II (Jena: Eugen Diederichs Verlag, 1914); C. Th. Sørensen, Europas havekunst fra Alhambra til Liselund (København: G. E. C. Guds forlag, 1959); Christopher Thacker, The History of Gardens (London: Croom Helm, 1979); Patrick Taylor, ed., The Oxford Companion to the Garden (Oxford: Oxford University Press, 2006). ediin, maisema-arkkitehtuurin modernisteista parhaassa tapauksessa Roberto Burle Marxiin. ${ }^{15}$

Insinöörisuunnittelu oli kiinteässä ammatillisessa yhteydessä arkkitehtuuriin 1700- ja1800-luvuille asti, jolloin alojen tehtäväkenttä ja koulutus alkoivat erkaantua. Vielä sen jälkeenkin arkkitehdit ovat voineet suunnitella myös rakennusten rakenteita, mutta vaativammat suunnittelukohteet - ensin teräs-, ja sitten betoni- ja teräsbetonirakenteet - ovat edellyttäneet insinöörien erikoisasiantuntemusta. ${ }^{16}$ Rakennustekninen kehitys eteni nopeasti samalla kun suunnittelukohteiden mittasuhteet kasvoivat. Poikkeuksellisen innovatiiviset insinööritaidon näytteet saattoivat saada laajaa huomiota ja kansallista tai kansainvälistäkin statusta, tunnetuimpana esimerkkinä arkkitehtuurihistorian yleiseen kaanoniin yltänyt Eiffel-torni (1889).

Kumpikin edellisistä aihepiireistä liittyy muihinkin tutkimusaloihin kuin taidehistoriaan. Puutarhat ja kaupunkipuistot ovat Suomessa, kuten muuallakin, olleet kulttuuri- ja aatehistoriallisen sekä kansatieteellisen tutkimuksen kohteina. ${ }^{17}$ Niitä on tutkittu myös maisema-arkkitehtuu-

15 Ks. esim. Hugh Honour \& John Fleming, A World History of Art, 7th ed. (London: Laurence King, 2009); Francis D. K. Ching, Mark M. Jarzombek \& Vikramaditya Prakash, A Global History of Architecture, 3rd ed. (Hoboken: Wiley, 2017); John Fleming, Hugh Honour \& Nikolaus Pevsner, The Penguin Dictionary of Architecture (London: Penguin, 1991).

16 Hazel Conway \& Rowan Roenisch, Understanding Architecture. An Introduction to Architecture and Architectural History, 2nd ed. (New York \& London: Routledge, 2005), 14, 17; Eeva Maija Viljo, Theodor Höijer. En arkitekt under den moderna storstadsarkitekturens genombrottstid i Finland från 1870 till sekelskiftet (Helsinki: Suomen Muinaismuistoyhdistys, 1985), 12-13.

17 Rainer Knapas, Monrepos. Ranskalaisen kulttuurin pohjoinen keidas (Helsinki: SKS, 2008); Bo Lönnqvist, Vanhoja kartanoita Helsingin seudulla: kulttuurihistoriallisia ajankuvia (Espoo: Schildts, 1995); Rauno Lahtinen \& Hannu Laaksonen, Kävelyllä puistojen Turussa (Turku: Turkuseura, 2008). 


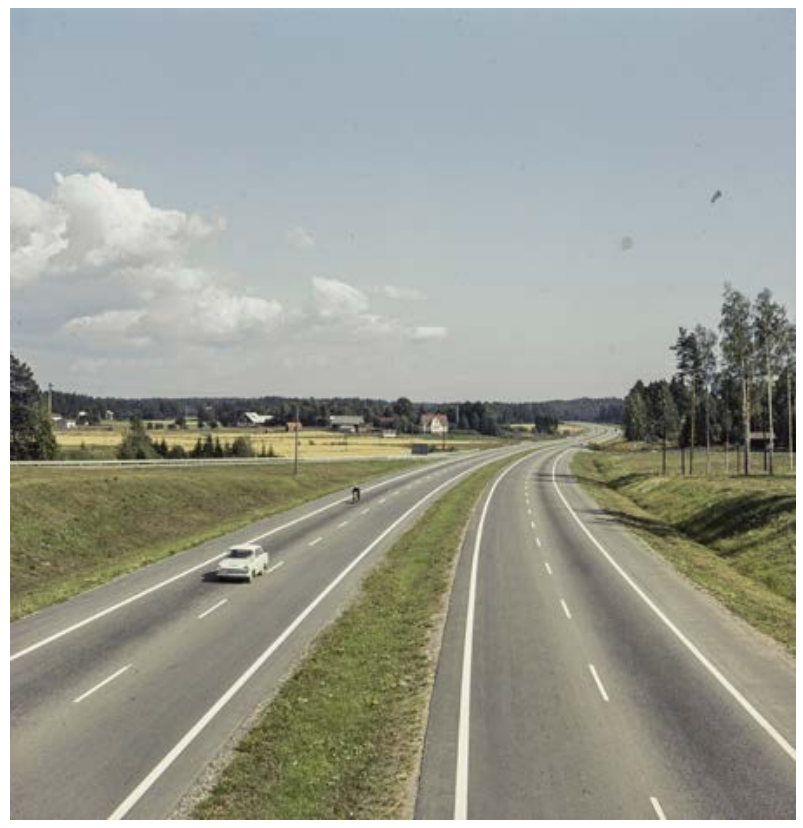

Kuva 1. Taidehistorian tutkijaa voi kiinnostaa esimerkiksi Tarvontiessä se, miten fyysisen rakennushankkeen ohesta voi uuttaa esiin moottoriteihin liittyvän visuaalisten mielikuvien ja tavoitteiden rinnakkaistodellisuuden. Suomessa ja muualla teistä haluttiin tehdä kaarevia ja tästä kaarevuudesta haluttiin ottaa kuvia. Kuva: Museovirasto, Historian kuvakokoelma, Matkailun edistämiskeskuksen kokoelma / H. T. Lehmusto 1963. Lähde: Finna.fi.

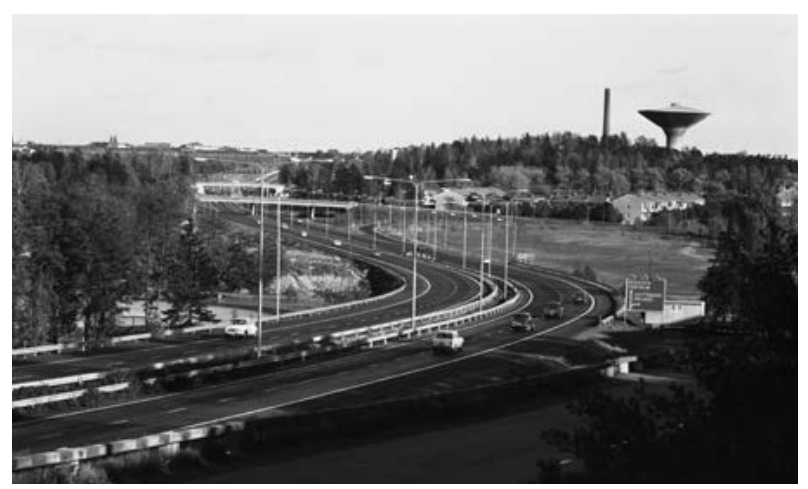

Kuva 2. Myös Simo Rista oli huomannut moottoriteiden kiinnostavat muodot ja kontrastit maisemassa. Tässä näkymässä Länsiväylä halkoo Lauttasaarta Helsingissä. Kuva: Helsingin kaupunginmuseo / Simo Rista SER 1970. Lähde: Finna.fi. rissa. ${ }^{18}$ Materiaalisen kulttuurin tutkimuskin on näkökulmana mahdollinen ${ }^{19}$ ja kaupunkipuistot sisältyvät osa-alueena myös kaupunkihistoriaan tai yhteiskuntatieteelliseen kaupunkitutkimukseen. ${ }^{20}$ Kaikilla näillä aloilla puutarhoja ja puistoja voidaan tarkastella myös taiteena, mutta niiden näkökulmat eivät samassa mitassa kytkeydy tutkimuskohteen taidestatukseen, eikä niissä ole pyritty tarkastelemaan kohteita taidekaanonien osina. Lähialojen ja taidehistorian välinen raja-aita on madaltunut, mutta painotusero edelleen olemassa, kuten tulemme osoittamaan. Insinöörirakentamista voidaan niin ikään tutkia materiaalisena kulttuurina tai kaupunkihistorian osa-alueena. ${ }^{21}$ Ilmeinen tieteellinen konteksti varsinaisen teknologiatutkimuksen ohella on tekniikan historia, joka usein näyttäytyy teknisten innovaatioiden ajallisena ketjuna. ${ }^{22}$ Teknologia ei kuitenkaan synny tyhjiössä, deterministisesti, vaan on yhteydessä taloudelliseen, poliittiseen ja sosiaaliseen kehitykseen, muistuttaa Susanna Santala. Hän on väitöstutkimuksessaan tarkastellut arkkitehti Eero Saarisen työskentelyä ja lentokentän rakennustyypin, sen typologian, ottamista osaksi modernin arkkitehtuurin kaanonia. ${ }^{23}$ Sigfried Giedion taas on kirjassaan

18 Ranja Hautamäki, Kartanot kaupungissa. Helsingin kartanoympäristöjen kaupunkimaistuminen, säilyttäminen ja yhteensovittaminen kaupunkirakenteeseen (Espoo: Aalto-yliopisto, 2016).

19 Chandra Mukerji, "The landscape garden as material culture: lessons from France", in The Oxford Handbook of Material Culture Studies, ed. Dan Hicks \& Mary Beaudry (Oxford: Oxford University Press, 2010).

20 Marjatta Hietala, Services and Urbanization at the Turn of the Century. The Diffusion of Innovations (Helsinki: Suomen Historiallinen Seura, 1987); Timo Kopomaa, Kaupunkipuiston käytöt: elämää Helsingin puistoissa ja ulkoilualueilla (Helsinki: Helsingin kaupungin tietokeskus, 1995).

21 Ron Eglash \& al., "Technology as material culture", in Handbook of Material Culture, ed. Christopher Tilley et al. (London: Sage, 2006); Hietala, Services and Urbanization, 179-258.

22 Hurme, Riitta et al., Betoni Suomessa 1860-1960.

23 Susanna Santala, Laboratory for a New Architecture: The Airport Terminal, Eero Saarinen and the Historiography of Modern Architecture (Helsinki: Helsingin yliopisto, 2015.)

\section{TaHiTi 2/2021 $\mathbf{y}$}


Space, Time, and Architecture (1941) kiinnittänyt huomiota teihin pyrkien tuomaan ne osaksi arkkitehtuurin historiaa. Giedion on oikeuttanut teiden sisällyttämisen kaanoniin modernismin sekä vielä tarkemmin mobiliteetin käsitteen kautta. ${ }^{24}$ Vaikka näillä alueilla saatetaankin etääntyä varsin kauas suoranaisesta taiteeksi määrittelemisestä, insinöörirakentamisen estetiikkaa voidaan tutkia myös ilman sitä, kuten artikkelissa osoitamme.

\section{Taidehistorian laaja kenttä ja sen rajat}

Kaupunkitutkimus on monitieteinen tutkimusalue, jolla taidehistoria on jo pitkään pyrkinyt irtautumaan pelkästään taiteeksi määrittyvien ilmiöiden tutkimisesta sekä sen myötä tekijäja teoskeskeisyydestä niin kansainvälisesti kuin Suomessakin. Esimerkkeinä tästä toimivat Riitta Nikulan ja Kirsi Saarikankaan tutkimukset: kumpikin heistä on tutkinut kaupunkisuunnittelua historiallisessa, sosiaalisessa ja kulttuurisessa kontekstissa ja käsittelee ympäristön merkityksiä teosnäkökulmaa kokonaisvaltaisemmin. Kuten Nikula on todennut, akateemisen taidehistorian rinnalla myös antikvaarinen kaupunkitutkimus on kiinnostunut vähemmän arvostetuista kaupunkiympäristön osista. ${ }^{25}$ Jos kaupunkia halutaan tutkia kokonaisvaltaisesti tilan tuottamisen ja siihen osallistuneiden ammattiryhmien

24 Sigfried Giedion, Space, Time and Architecture. The growth of a new tradition (Cambridge: Harward University Press, 1941 [1952], 623.

25 Riitta Nikula, "Kaupunkitutkimus", teoksessa Katseen rajat, taidehistorian metodologiaa, toim. Arja Elovirta \& Ville Lukkarinen (Helsinki: Helsingin yliopisto, 1998); Kirsi Saarikangas, "Tilan tekijät", teoksessa Katseen rajat, taidehistorian metodologiaa, toim. Arja Elovirta \& Ville Lukkarinen (Helsinki: Helsingin yliopisto, 1998); Kirsi Saarikangas, Asumisen muodonmuutoksia. Puhtauden estetiikka ja sukupuoli modernissa arkkitehtuurissa (Helsinki: SKS, 2002). Jo 1970-luvun kotimaisessa taidehistoriassa keskusteltiin koko rakennetun ympäristön kattavasta "miljöötutkimuksesta", jota lähestyttiin morfologisella otteella: Henrik Lilius, "Miljöötutkimuksen menetelmistä ja tavoitteista," teoksessa Taidehistoria ja ympäristöntutkimus, toim. Leena Arkio \& Kalevi Pöykkö (Helsinki: Gaudeamus, 1975). näkökulmasta, tutkimuksen pitää kohdistua muidenkin kuin arkkitehtien suunnittelemiin rakennuksiin tai ympäristöihin. Kokonaiskuvaan kuuluu monien muiden ryhmien aikaansaannoksia ja näiden yhteisvaikutuksesta syntynyt urbaani kudelma, jonka keskeinen osa ovat myös arkiset tilakäytännöt ja kokemukset. ${ }^{26}$

Muuallakin kuin kaupungeissa moninaiset toimijaryhmät ovat arkkitehtien rinnalla osallistuneet rakennetun ympäristön tuottamiseen: rakennusmestarit ${ }^{27}$, insinöörit tai puutarhurit, puutarha- ja maisema-arkkitehdit, taiteilijat sekä muut kuin ammattisuunnittelijat. Taidehistoriallista tutkimusta on kuitenkin hallinnut institutionaalisesti määrittynyt arkkitehtuuri. Arkkitehtuurin asema taiteenalana ja arkkitehtien taiteilijoina on yksiselitteinen ja pitkän tutkimusperinteen vakiinnuttama. Väitämme, että muiden rakennettua maisemaa suunnitelleiden ryhmien käsittelyä taidehistoriallisessa tutkimuksessa on oikeutettu niiden toiminnan analogisuudella arkkitehteihin nähden tai läheisellä yhteistyöllä ja vuorovaikutuksella arkkitehtien kanssa, jolloin taidestatukseen perustuva tutkimuskohteen rajaus on koskettanut näitä epäsuorasti.

Puutarhurit eivät ole ainakaan Suomessa pyrkineet asemoimaan itseään taiteilijoiksi, vaikka olisivat suunnitelleet merkittäviäkin ympäristökokonaisuuksia. Ulkomailla koulutetut puutarha-arkkitehdit ovat saattaneet näin tehdäkin, mutta alan taidestatusta ei ole tunnustettu sen oman piirin ulkopuolella. ${ }^{28}$ Insinööreistä puolestaan osa on toiminut rakennussuunnittelussa läheisessä yhteydessä arkkitehteihin, osa taas infrastruktuurirakentamisessa, joka on voinut

Vrt. Henri Lefebvre, The Production of Space (Oxford: Blackwell, 1991).

27 Renja Suominen-Kokkonen, Rakennusmestariarkkitehtuuri Suomessa ja sen taustalla ollut koulutus. Rakennusmestarit ja teollisuuskoulujen huonerakennusosastojen koulutus 1885-1911 (Helsinki: Helsingin yliopisto, 1989).

28 Maunu Häyrynen, "Suomalainen puutarha", teoksessa Hortus Fennicus, Suomen puutarhataide, toim. Maunu Häyrynen ja muut (Helsinki: Viherympäristöliitto, 2001). 


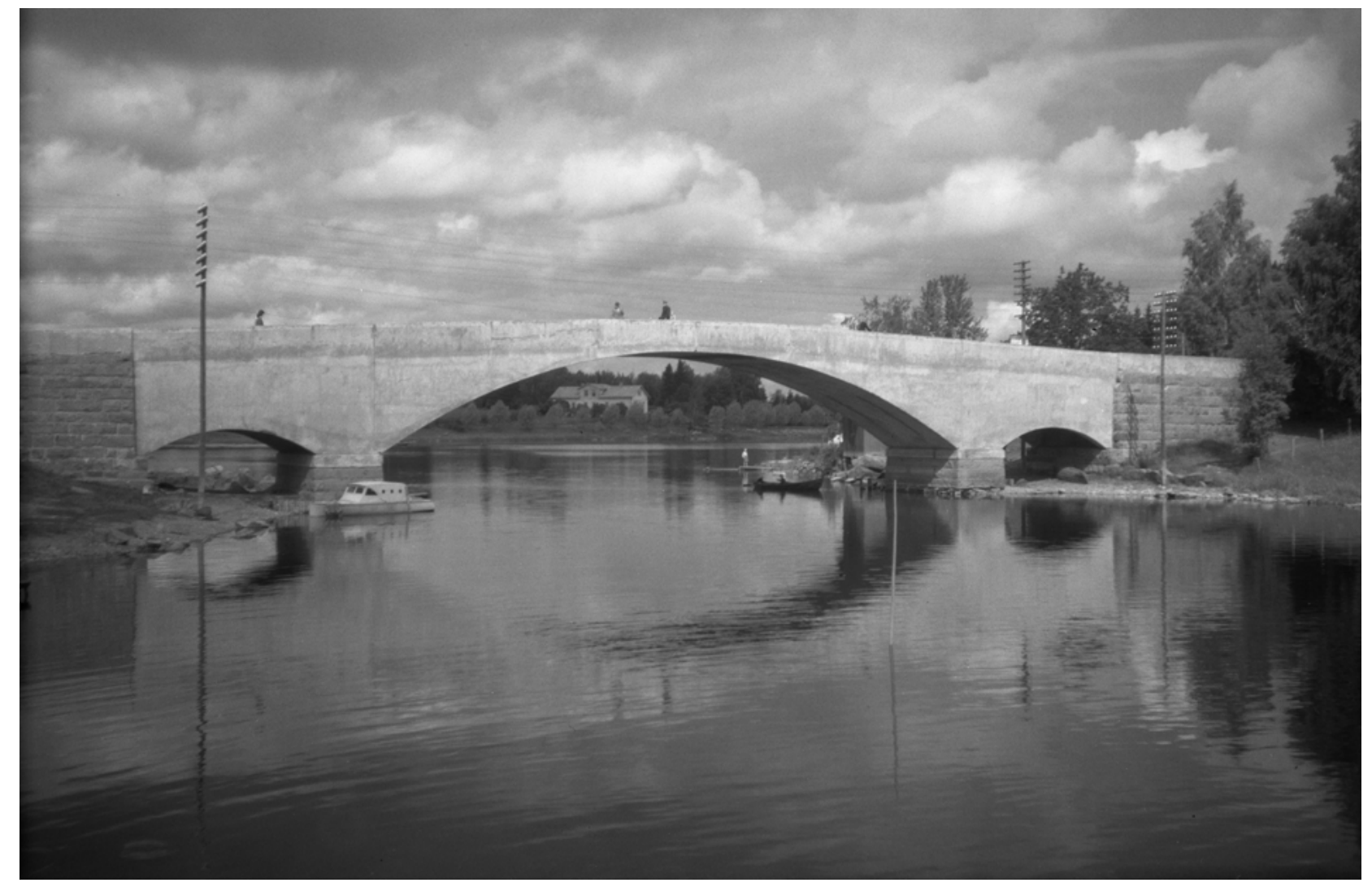

Kuva 3. Vuonna 1919 valmistunut Mierolan silta Hämeenlinnan Hattulassa. Mierolan sillan suunnitteli ja toteutti Oy Constructor Ab, jonka muihin tunnettuihin teräsbetonisiltoihin kuuluivat mm. Tampereen kiviverhoiltu Hämeensilta ja Kouvolan Korian rautatiesilta. Paljon kuvatun sillan suunnittelijaksi arvellaan Wäinö Wuoliota, mutta paremmin tiedossa on sen ulkoasun suunnitellut Frosterus-Gripenbergin arkkitehtitoimisto. Kuva: Matti Poutavaara 1919. Lähde: Finna.fi.

mittakaavallisesti ja visuaalisesti rinnastua arkkitehtien suunnittelemiin ympäristöihin esimerkiksi tie- ja siltarakentamisessa.

Taidehistorian tutkimusalueen entistä vapaampi ja monimuotoisempi määrittely tuottaa mielenkiintoisen tilanteen. Laajimmillaan taidehistorian tutkimuskenttä lähenee kulttuurintutkimusta. ${ }^{29}$ Taidehistorian piiriin kuuluvat silloin periaatteessa kaikki rakennetun ympäristön ja siinä eletyn arjen ilmiöt, ja niitä voi tarkastella yhtä oikeutetusti historiallisin, etnografisin tai yhteiskuntatieteellisin menetelmin, konstruktionistisesta, fenomenologisesta tai uusmaterialisti-

29 Ville Lukkarinen, "Taiteen tarina", teoksessa Katseen rajat, taidehistorian metodologiaa, toim. Arja Elovirta \& Ville Lukkarinen (Helsinki: Helsingin yliopisto, 1998), 52-53. sesta näkökulmasta. Napanuora taiteeseen ja sen osana arkkitehtuuriin, samoin moniin taidehistorian tieteenalaperinnettä kantaviin keskusteluihin, voi tällöin päästä venymään pitkäksi. Kaiken kontekstualisoinnin keskelläkään taidehistoria ei silti ole kokonaan irtautunut taiteen kaanoneista. Taidehistoriassa vaikuttaa siis olevan sisäkkäisiä tieteenalarakenteita, jolloin keskenään ristiriitaisiakin suhtautumis- ja rajaustapoja suhteessa rakennettuun ympäristöön voi esiintyä sen piirissä rinnakkain.

\section{Nimetön kanssarakentaja ja näkymättömät maamerkit}

Rakennustekniikan alan koulutus alkoi Suomessa jo 1800-luvun puolivälissä. Teräs- ja teräsbetonirakenteiden yleistyminen 1800-luvun

\section{TaHiTi 2/2021 $\mathbf{\Xi}$}


lopulla toi rakennetun ympäristön pariin siihen erikoistuneet suunnittelijat, joista vain harvat olivat arkkitehteja. 1900-luvun vaihteessa kehitetyt teräsbetonirakenteet vaativat oman erityisosaamisensa. Ne ilmaantuivat tehdasrakennusten lisäksi monumentaalirakentamiseen, mutta niiden suunnittelijat - kuten lukuisien tunnettujen kohteiden rakenteita suunnitellut Jalmar Castrén - jäivät taidehistoriassa enimmäkseen vaille huomiota. Vaikka teollisuus- ja infrastruktuurirakennuksissa arkkitehtuurin rooli saattoi alusta asti jäädä toiselle sijalle rakenne- ja muuhun tekniseen suunnitteluun nähden, näidenkin rakennusten kohdalla lähinnä arkkitehdit tuodaan esiin suunnittelijoina. Esimerkiksi SOK:n viljasiilorakentamisen käynnistäneen Viipurin myllyn suunnittelijoiksi nimetään Erkki Huttunen ja Valde Aulanko. Rakenteista vastannutta Jaakko Packalénia sen sijaan ei mainita, vaikka rakennuksen ulkoasu perustui olennaisesti liukuvalutekniikkaan. Tiivis yhteistyö konstruktöörin kanssa oli ominaista monelle muullekin modernistiarkkitehdille, ei vähiten Alvar Aallolle, mutta hänenkin tuotantonsa yhteydessä rakennesuunnittelijat jäävät taustalle. ${ }^{30}$

1900-luvun mittaan luotiin myös paljon huomiota saaneita maamerkkirakennelmia, joissa arkkitehdeilla ei ollut osaa eikä arpaa. Tällaisia olivat monet tunnetut teräsbetonisillat, kuten Constructor Oy:n Tampereen Hämeensilta ja Korian rautatiesilta tai Tie- ja vesirakennushallituksen insinöörin Erkki Lappi-Seppälän suunnittelema Naantalinsalmen eli "Ukko-Pekan" silta. Siinä missä monumentaalisia siltoja rakennutti nuori valtio, kunnat alkoivat pystyttää betoni-

30 Lauri Putkonen, "Betonin käyttö talonrakennuksessa 1800-Iuvun lopulta 1930-luvulle", teoksessa Betoni Suomessa 1860-1960, toim. Riitta Hurme ja muut (Helsinki: Suomen Betoniyhdistys, 1991); Ritva Wäre, "Arkkitehtuuri vuosisadan vaihteessa," teoksessa ARS Suomen taide 4, toim. Salme Sarajas-Korte ja muut (Helsinki: Otava 1989); Riitta Nikula, "Rakennustaiteen 1920- ja 1930-luku", teoksessa ARS Suomen taide 5, toim. Salme Sarajas-Korte ja muut (Helsinki: Otava 1990). Wäre kiinnittää Suvilahden voimalaitoksen kohdalla huomiota arkkitehti Selim Lindqvistin ja konstruktööri Jalmar Castrénin tiiviiseen yhteistyöhön. rakenteisia vesitorneja, joista usea muodostui paikalliseksi maamerkiksi päätyen kuvittamaan matkailuviirejä ja postikortteja. Ikonisimpien vesitornien suunnittelijoina saatettiin nimetä arkkitehtien lisäksi myös insinöörejä, kuten Haukilahden kuorirakenteisessa vesitornissa Ilmari Hyppänen arkkitehti Eero Virkkusen rinnalla. ${ }^{31}$

Motorisoituvan Suomen tiestöä ja tieverkkoajattelua kehitettiin pääosin muualla kuin arkkitehtipiireissä. Sodanjälkeisen ajan merkkipaalu, ensimmäiset noin 13 kilometriä moottoritietä suunniteltiin, rakennettiin ja tuotettiin kuitenkin lopulta yhdistelmänä insinöörien, suurelle yleisölle raportoivien toimittajien ja arkkitehtien keskusteluja. Vuosina 1956-1962 rakennetun, Helsingin Munkkivuoresta Espoon Gumböleen ulottuvan Tarvon moottoritien suunnittelivat TVH:n insinöörit Väinö Skogström, Gunnar Piponius ja Pentti Polvinen. Taustalla oli vahvasti Helsingin vuoden 1946 alueliitos, joka yhdistettynä muuttoliikettä Helsinkiin kasvattaneeseen taloudelliseen nousukauteen ja uuden asuntorakentamisen kaupunkirakennetta hajottavaan luonteeseen lisäsi vaatimuksia liikenteen kehittämiselle. ${ }^{32}$

Tarvon moottoritiestä puhuttiin ensinnäkin tieinsinöörien omassa, Arkkitehti-lehteen vertautuvassa ammattijulkaisu Tielehdessä, jossa taidehistorioitsijaa kiinnostavia, estetiikkaan liittyviä lausumia esiintyy harvakseltaan siellä täällä. Gunnar Piponius kirjoitti itse "Tarvontien" tapausesittelyssä tien estetiikasta ensisijaisesti palvelemassa käyttäjää. Maisemaan harmonisesti linjattu tie auttoi suurta nopeutta ajavaa kuljetta-

31 Maunu Häyrynen, "Betonin käyttö sillan- ja vesirakennuksessa 1800-luvun lopulta 1960-luvun alkuun," teoksessa Betoni Suomessa 1860-1960, toim. Riitta Hurme ja muut (Helsinki: Suomen Betoniyhdistys, 1991); Ismo Asola, Vesitorni, yhdyskuntien maamerkki (Helsinki: Rakennusinsinöörien Liitto, 2003).

32 Timo Herranen, Hevosomnibusseista metroon. Vuosisata Helsingin joukkoliikennettä (Helsinki: Helsingin kaupungin liikennelaitos, 1988), 232. 
jaa keskittymään. ${ }^{33}$ Samalla kun valtalehdistöstä esimerkiksi Uuden Suomen Kuvalehti maiskutteli tällä "todellisella toivetiellä" ${ }^{4}$, arkkitehdit olivat huomanneet lupaavan hankkeen.

Tarvontie otettiin mukaan Suomi rakentaa 3 -näyttelyyn vuonna 1963, ja se sai näin virallisen arkkitehtuuri-instituution hyväksynnän. ${ }^{35}$ Tämän artikkelin kannalta on kiinnostavaa, miten näyttelyn tuomaristo puhui kohteesta: se oikeutettiin suoraan arkkitehtuurin alle, vaikka sen suunnittelijat edustivat aivan toista alaa. Arkkitehdissä julkaistiin dialogin muodossa Suomi rakentaa 3:en "jälkipuinti" eli 3.5.1963 Rakennustaiteen museossa pidetty keskustelutilaisuus, jossa käsiteltiin näyttelyn sisältöjä ja valintoja. Dialogista käy ilmi, miten approprioivasti tiehen suhtauduttiin (kursivoinnit omia).

Arkkitehti Esko Suhonen tiivisti tuomariston näkemyksen näyttelyn sisällöistä toteamalla, että: "Useat ovat moittineet, ettei tällä näyttelyllä ollut varsinaista teemaa. Näyttelyllä oli kuitenkin aivan selvä teema: se halusi osoittaa kuinka arkkitehtuuri on tärkeä elementti koko inhimillisen elämän eri aloilla. Lähtien tiesuunnittelusta ja päätyen yksityisiin asuntoihin ja käsitellen kaikkea muuta tältä väliltä.” Arkkitehti Olof Hansson kiteytti kollegansa sanoman ja Suomi rakentaa 3:n päämäärät: "Valitessaan töitä näyttelyyn jury pyrki sitä periaatetta [sic], että kultakin sektorilta valittiin töitä, jotka pyrkivät näyttämään $a r k k i$ tehtuurin aktuellit probleemit." ${ }^{36}$

Vuoden 1966 kolmannessa numerossa Tielehdessä uutisoitiin yhden sivun verran Rakennustaiteen museon kevätkauden aloittaneesta tapa-

33 Gunnar Piponius, "Tarvon - Gumbölen autotie," Tielehti nro. 4 (1957): 39-45.

34 "Tulevaisuuden tie," Uuden Suomen Kuvalehtinro. 6-7 (1957).

35 Martti Jaatinen, toim., Suomi rakentaa 3: nykyarkkitehtuurin näyttely Taidehallissa. 23.3.-15.4.1963 (Helsinki: Suomen Rakennustaiteen museo, 1963).

36 "Suomi rakentaa III. Jälkipuinti," Arkkitehti nro. 4 (1963): 27, 28. uksesta: arkkitehti Martti I. Jaatinen oli koonnut näyttelyn Tie suomalaisessa maisemassa, jossa esiteltiin täkäläistä tieympäristöä "geomorfologisiin maisema-alueisiin jaettuna". Lehdessä kerrottiin, että "[- - ] näyttely tuo selvästi ja havainnollisesti esille eräitä tien suunnitteluun ja estetiikkaan liittyviä perusajatuksia myönteisessä hengessä. Tämä on näyttelyn suurimpia ansioita: onhan tie aikaisemmin ollut usein esillä eräiden kulttuurihistoriallisesti epäonnistuneiden ratkaisujen muodossa." ${ }^{37}$ Tiekysymys oli jälleen saanut virallisen arkkitehtuuri-instituution hyväksynnän. Seuraavana vuonna 1967 julkaistiin Jaatisen samanniminen kirja. ${ }^{38}$ Se lienee taidehistorian tutkimuksessa vähälle huomiolle jääneen tiesuunnittelun aihealueen tunnetuin teos 1960-luvulta, jolloin moottoriteiden rakentaminen lähti Suomessa käyntiin.

Asemakaavoituksen professori ja moniottelija Otto I. Meurman otti jo 1940-luvulla kantaa luonnonympäristön huomioon ottamisen puolesta. Myös hän piti Tielehteä hyvänä foorumina. Vuonna 1949 julkaistussa kirjoituksessaan "Tie ja maisema" Meurman peräänkuuluttaa insinöörisuunnittelijoilta hyvää makua: työt pitää sijoittaa luontoon kauniisti ja hienovaraisesti. Tie ei saa olla "haava", se tulee sijoittaa maisemaan luontoarvot huomioiden. ${ }^{39}$

Kaikesta päätellen voisi luulla, että genrensä ensimmäisenä Suomessa Tarvon moottoritie olisi päässyt osaksi modernistisen arkkitehti- ja kaupunkisuunnittelun kaanonia. Näin ei kuitenkaan käynyt. Voi sanoa, ettei tässä onnistunut edes Sigfried Giedion, vaikka hän retoriikassaan nostaa moottoriliikenteelle tarkoitetut tiet yhdeksi modernin ajan suunnannäyttäjäksi mui-

37 "Tie Suomen maisemassa," Tielehti nro. 3 (1966): 19. Itse asiassa Jaatinen oli ollut Suomi rakentaa 3 -näyttelyn komissaari, joten Tarvon moottoritie oli todella keskusteluissa mukana. Ibid.; Arkkitehti nro. 4 (1963).

38 Martti I. Jaatinen, Tie suomalaisessa maisemassa (Porvoo: WSOY, 1967).

39 Otto I. Meurman, "Tie ja maisema," Tielehti nro. 1 (1949): 2-5.

\section{TaHiTi 2/2021 $\mathbf{y}$}


den arkkitehtuuri-ilmiöiden rinnalle, ja esittelee sitä malliesimerkkinä tila-aika -käsitteestään. ${ }^{40}$ Äärimmäisellä rasituksella olleet moottoritiet kenties hukkuivat siinä määrin omaan funktionaalisuuteensa, ettei arkkitehtikunta jaksanut ylläpitää niiden statusta visuaalisena taiteena.

\section{Arkkitehdin luomus "luonnossa" tai "puistomaisessa ympäristössä"}

Ensimmäiset tiedossa olevat puutarhojen suunnittelijat olivat Suomessa niiden omistajia, ja suunnittelu oli harrastus. Suunnitteluun mahdollisesti osallistuneet ammattipuutarhurit jäivät useimmiten nimettömiksi, eikä heidän roolistaan ole tarkkaa kuvaa. Vasta 1800-luvun alkupuolella kuvaan ilmestyi suunnittelevia puutarhureita, jotka usein tulivat Suomen ulkopuolelta. Näidenkin suunnittelutyö on vain osaksi dokumentoitunut. 1800-luvun lopulla puutarhureita alkoivat palkata yksityisten lisäksi Valtionrautateiden tapaiset valtiolliset tahot ja suuremmat kaupungit. Tältä ajalta on jo säilynyt varsinkin julkisille toimijoille tehtyjä suunnitelmia. Vasta yksityisyrittäjinä toimineet puutarha-arkkitehdit, joista ensimmäisinä aloittivat Paul Olsson ja Bengt Schalin 1910-luvulla, pitivät yllä omia suunnitelma-arkistojaan. ${ }^{41}$

Ensimmäisiä Suomessa toimineita yksityisiä puutarhasuunnittelijoita oli Tanskan kuninkaallisessa taideakatemiassa puutarhurikoulutuksensa saanut monitoimimies Mårten Gabriel Stenius, joka taidehistoriassa esiintyy Eliel Saarisen Munkkiniemi-Haaga-suunnitelman 1915 tilaajana. Stenius oli tämän lisäksi muun muassa Turun Vartiovuoren puiston ja useiden kartanopuistojen pääsuunnittelija. Hänen suunnitelmiaan on säilynyt vain satunnaisesti. Yllä mainitut puutarha-arkkitehdit työskentelivät paljon yhteistyössä arkkitehtien kanssa: Paul Olsson

40 Giedion, Space, Time and Architecture, (1941) 1952.

41 Häyrynen, "Suomalainen puutarha". suunnitteli muun muassa Olympiakylän istutukset ja teki myös Jarl Eklundin kanssa yhteistyötä. Bengt Schalinin tunnetuimpiin kohteisiin kuului Sigurd Frosteruksen suunnitteleman Vanajanlinnan puutarha. Sekä Olsson että Schalin suunnittelivat puutarhaympäristöjä arkkitehtonisesti merkittävälle Noormarkun ruukkialueelle. ${ }^{42}$

Kotimaisen arkkitehtuurihistorian yleisesityksissä yllä kuvatun kaltainen yhteistyö puutarhasuunnittelijoiden kanssa on viime vuosiin asti näkynyt satunnaisesti. ${ }^{43}$ Rakenesuunnittelijoiden työ on voitu selittää alisteiseksi arkkitehtoniselle muodonannolle, mutta puhuttaessa rakennusten ympäristöistä tämä selitys pätee huonommin. Pihojen ja puutarhojen suunnittelu on sekin voinut olla alisteisessa roolissa rakennusten kehyksenä. Se on kuitenkin voinut myös käydä vuoropuhelua tai jopa kilpailla arkkitehtuurin kanssa. Olennaista on, että pihat ja puutarhat ovat tietoisesti ja itsenäisesti omien periaatteidensa mukaan suunniteltuja kokonaisuuksia. Silloin ei ole perusteltua jättää niitä sivurooliin arkkitehtien toiminnan rinnalla rakennetun ympäristön tutkimuksessa.

Arkkitehtikeskisyyden tekee entistäkin mielenkiintoisemmaksi se, että puistosuunnitteluakin on voitu analysoida kotimaisissa arkkitehtuurihistorian yleisesityksissä silloin kun suunnittelijana on ollut arkkitehti. Helsingin Keskuspuisto toimii tästä hyvänä esimerkkinä. Keskuspuiston Töölönlahdelta maaseudulle ulottuvana vihervyöhykkeenä kehitti kaavallisena ideana vuonna

42 Helena Soiri-Snellman, "Turun Vartiovuorenpuisto", teoksessa Hortus Fennicus, Suomen puutarhataide, toim. Maunu Häyrynen ja muut (Helsinki: Viherympäristöliitto, 2001); Maunu Häyrynen, "Mårten Gabriel Stenius," Kansallisbiografia, toim. Matti Klinge (Helsinki: Suomalaisen Kirjallisuuden Seura, 2003); Eeva Ruoff, "Paul Olsson", Kansallisbiografia, toim. Matti Klinge (Helsinki: Suomalaisen Kirjallisuuden Seura, 2003); Tuula-Maria Merivuori, "Bengt Schalin ja vuosisadan alun muotopuutarha," teoksessa Hortus Fennicus, Suomen puutarhataide, toim. Maunu Häyrynen ja muut (Helsinki: Viherympäristöliitto, 2001).

43 Jouni Kaipia \& Lauri Putkonen, A Guide to Finnish Architecture (Helsinki: Otava, 1997). Opas nimeää isä ja poika Olssonin sekä Bengt Schalinin lisäksi Gretel Hemgårdin nykymaisema-arkkitehtuurin edustajaksi. 


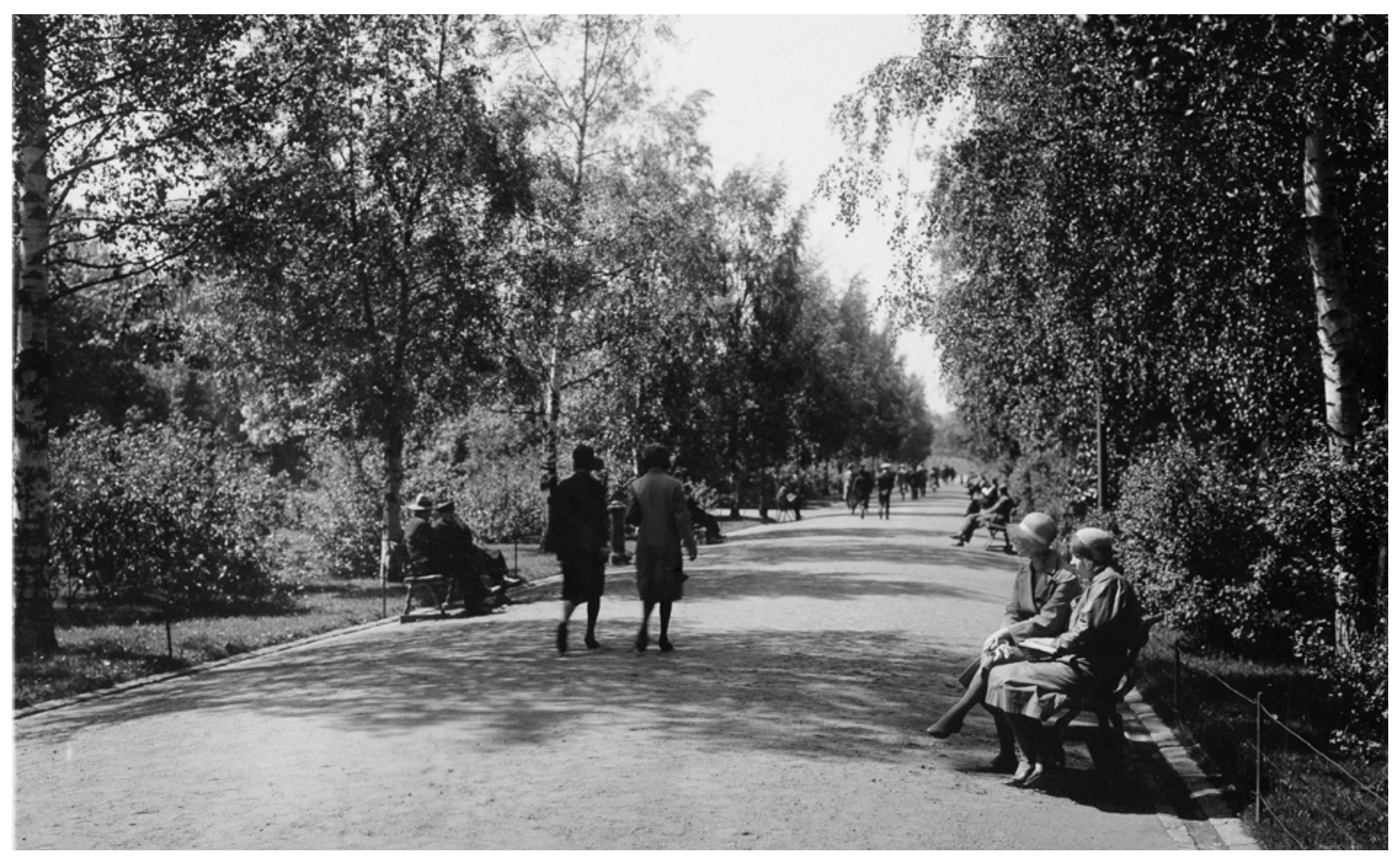

Kuva 4. Kaisaniemen puiston pääkäytävä 1930-luvulla. Kaisaniemen puiston suunnitteluhistoriaan on eri vaiheissa liittynyt niin arkkitehteja kuin puutarhureita ja maisema-arkkitehteja, mutta taidehistorian yleisesityksissä mainitaan useimmiten puiston varhaisvaiheen suunnittelijoina Johan Albrecht Ehrenström ja Carl Ludvig Engel, myöhemmissä vaiheissa taas kaupunginasemakaava-arkkitehdit Bertel Jung ja Birger Brunila. Näiden lisäksi puistoa ovat olleet suunnittelemassa mm. kaupunginpuutarhurit L. A. Jernström ja Svante Olsson, puutarha-arkkitehti Paul Olsson sekä viime vaiheissa maisema-arkkitehtitoimistot Maisemasuunnittelu Hemgård ja Näkymä Oy. Kuva: Helsingin kaupunginmuseo / G. Herlin 1930-1939. Lähde: Finna.fi.

1911 kaupunginasemakaava-arkkitehti Bertel Jung, joka myös visioi puiston fyysistä toteutusta. Töölönlahden ja Eläintarhan puistovyöhykettä oli kuitenkin alettu ideoida jo vuodesta 1898 ja se toteutui Helsingin kaupunginpuutarhuri Svante Olssonin suunnitelmien pohjalta. Jungin puistoalueen jatkoksi lisäämä metsäinen kiila muutti sen kansainvälisten mallien mukaiseksi vihervyöhykkeeksi, mutta ei silti siirtänyt toisen ammattiryhmän edustajan hyvin suunnitelmissa ja aikalaiskeskustelussa dokumentoitunutta mittavaa suunnittelutyötä kaupunginasemakaava-arkkitehdin tekemäksi. Arkkitehtien kirjoituksissa kaupunginpuutarhurin roolia ei kuitenkaan noteerattu. ${ }^{44}$

44 Häyrynen, Maisemapuistosta reformipuistoon; Riitta Nikula, Suomen arkkitehtuurin ääriviivat (Helsinki: Otava, 2005), 114-115; Riitta Nikula, "Bertel Jung modernin kaupunkisuunnittelun käynnistäjänä".
Michel Foucault'ta seuraten tekijyys on keskeinen taideteoksen ja niistä muodostuvien tuotantojen, tyylien, periodien ja kaanonien määre ja siihen kuuluu olennaisesti tekijän nimeäminen.$^{45}$ Taidehistoriallisissa yleisesityksissä poissulkeminen tapahtuu yleensä nimeämättä jättämisenä. Nimettömästi tuotettujen objektien tekijäfunktio liudentuu. Arkkitehtuuriteksteissä rajanvetoa tehdään esimerkiksi puhumalla nimeltä mainittujen arkkitehtien suunnittelemista rakennuksista, niiden ympäristöistä sen sijaan "luontona”, jolle tekijyys näin siirtyy. Esimerkiksi suomalaisen maisema-arkkitehtuurin modernismin kannalta keskeisen Tapiolan asemakaavoja ja rakennuksia suunnitelleita arkkitehteja nimetään säännön-

Michel Foucault, "What is an Author?," in Michel Foucault: Aesthetics, Method and Epistemology, ed. James Faubion (New York, The New Press 1969 [1998]). 
mukaisesti yleisesityksissä, maisema-arkkitehteja välttämättä ei. ${ }^{46}$

Taidehistorian valinnat heijastuvat kulttuuriympäristön suojeluun, missä suojeluperusteet johdetaan usein suoraan taidehistoriallisesta tutkimustiedosta. Valtakunnallisesti merkittävien rakennettujen kulttuuriympäristöjen luettelosta löytyy lukuisia esimerkkejä arkkitehtien ja puutarhasuunnittelijoiden yhteistyöstä, mutta suojeluarvo perustellaan usein vain arkkitehtien aikaansaannoksilla. Kärjistäen arkkitehdin suunnitteleman rakennuksen kerrotaan sijaitsevan "puistomaisessa ympäristössä" silloinkin, kun kyseinen ympäristö on ollut suunniteltu kokonaisuus, sen suunnittelija on yleisesti tiedossa ja suunnitelma-aineisto sekä julkaistua tutkimusta siitä olisi helposti saatavilla. Puutarha- ja maisema-arkkitehtuuri on kuitenkin saanut viime vuosina jonkin verran lisää jalansijaa suojeluluetteloissa, joten osaksi kyse lienee ollut viiveestä uudemman tutkimuksen hyödyntämisessä.

\section{Johtopäätökset}

Suomalaisen rakennetun ympäristön taidehistoriallisessa tutkimuksessa voidaan alan yleisesitysten ja suojeluluetteloiden pohjalta tunnistaa edelleen kaanon, jossa arkkitehtien toiminta ja tuotanto asettuvat etusijalle muihin ympäristöä suunnitelleisiin ammattiryhmiin nähden silloinkin, kun niiden edustajat ovat toimineet tiiviissä yhteistyössä arkkitehtien kanssa. Tämä ei merkitse sitä, etteivätkö insinöörisuunnittelu tai puutarha- ja maisema-arkkitehtuuri olisi hyvinkin legitiimejä osia kotimaisen taidehistorian tutkimuksessa. Yhtäältä taidehistoria on Suomessakin avoin monenlaisille kysymyksenasetteluille ja tieteenalanäkökulmille, toisaalta taidemäärittelyyn perustuvaan kaanoniin turvaudutaan edelleen herkästi silloin, kun aikaa ja tilaa on rajallisesti. Vain arkkitehtien nimet ja teokset erottuvat tällöin taustasta. Ilmiö ei ole uusi: vastaava nimettömyys on aiemmin langennut naisarkkitehtien osaksi.

Insinöörien ja puutarhasuunnittelijoidentapaukset poikkeavat jossain määrin toisistaan. Insinöörit ovat tuottaneet mittasuhteiltaan ja näkyvyydeltään arkkitehtuuriin rinnastuvaa maamerkkirakentamista. Niihin on voitu myös liittää esteettisiä tavoitteita, joskaan ei ilmaistuja taiteellisia intentioita, ja ammattikunta on tyytynyt keskustelemaan töistään oman alansa foorumeilla. Puutarhasuunnittelussa taiteellisia ambitioita on voinut esiintyäkin, mutta ympäröivä yhteiskunta ei ole juuri tunnistanut niitä. Viime vuosikymmeninä maisema-arkkitehtuuri on ammatillisesti rinnastunut arkkitehtuuriin, mutta on silti usein nähty sen anonyyminä jatkeena.

Osasyynä rajauksen tiukkuuteen voi olla arkkitehtien ammatillinen julkaisutoiminta, jossa on keskitytty enemmän arkkitehtien kuin muiden ammattiryhmien tekemisiin. Arkkitehtien tuottamat lähteet ovat puolestaan olleet keskeinen kotimaisen taidehistoriallisen arkkitehtuurihistorian tutkimuksen aineistopohja. Suomessa arkkitehtuurin, taidehistorian ja rakennussuojelun väliset institutionaaliset kytkökset ovat muutenkin perinteisesti tiiviitä, jolloin arkkitehtien julkaisuissa tehdyt valinnat ja painotukset ovat herkästi välittyneet myös taidehistorian tutkimukseen ja sen kautta kotimaisiin arkkitehtuurihistorian yleisesityksiin. Maisema-arkkitehtuurin muutos kiinteäksi osaksi arkkitehtikoulutusta ja ammattikuntaa näkyy jo muun muassa kotimaisissa arkkitehtuurialan ammattilehdissä ja näyttelytoiminnassa. Tämän kehityksen rekisteröityminen taidehistoriallisessa tutkimuksessa ja sen myötä yleisesityksissä kestää kuitenkin pitempään.

Niin kotimaista kuin kansainvälistäkin taide- ja arkkitehtuurihistoriallista kiinnostusta on osaltaan suunnannut myös suomalaisen arkkitehtuurin, ennen muuta modernismin, kansainvälinen arvostus. Suomalaiseen maisema-arkkitehtuuriin

\section{TaHiTi 2/2021 $\mathbf{\nabla}$}


se ei - Tapiolaa lukuun ottamatta ${ }^{47}$ - ole juuri yltänyt, ja vielä vähemmän varhaisempaan puutarhasuunnitteluun tai insinöörirakentamiseen. Kansainvälinen julkisuus ei ole ollut kanonisoinnin välttämätön ehto, mutta todennäköisyys etabloituneen arkkitehdin valikoitumiselle tutkimuskohteeksi on suurempi kuin vähemmän arvostetun alan edustajan.

Valtaosa suomalaisesta taidehistorian tutkimuksesta tehdään kotimaiselle yleisölle. Vaikka alalla ei enää ole roolia "kansallisena" tieteenä, rakennetaan kotimaisissa yleisesityksissä silti kansallista kaanonia, jonka piiriin on valikoivasti hyväksytty myös muiden kuin arkkitehtien tuottamaa rakentamista, kuten keskiaikaisia kivikirkkoja. ${ }^{48}$ Arkkitehtuurin kansallinen määrittely on ollut keskeinen tutkimusalue viime vuosikymmenten taidehistoriassa, joka on käsitellyt kiinnostavasti esimerkiksi kansainväliseksi mielletyn modernismin uudelleenkontekstualisoitumista suomalaisen rakennusperinteen jatkajaksi. ${ }^{49}$ Syystä tai toisesta kotimainen puutarhasuunnittelu tai maisema-arkkitehtuuri eivät kuitenkaan ole juuri päässeet yleisesityksissä kansallisen arkkitehtuurikaanonin piiriin.

Geoffrey Jellicoe \& Susan Jellicoe, The Landscape of Man, Shaping the Environment from Prehistory to the Present Day (London: Thames \& Hudson, 1995).

48 Preziosi, Rethinking Art History, 41; Leena Valkeapää, Pitäjänkirkosta kansallismonumentiksi. Suomen keskiaikaisten kivikirkkojen restaurointi ja sen tausta vuosina 1870-1920 (Helsinki: Suomen Muinaismuistoyhdistys, 2000).

49 Anne Mäkinen, Suomen valkoinen sotilasarkkitehtuuri 1926-1939 (Helsinki: Suomalaisen Kirjallisuuden Seura, 2000).
Kuten edellä on todettu, myös insinöörirakennelma voi saavuttaa kansallisen monumentin aseman, mutta Suomessa tästä on vaikea löytää esimerkkejä. Toki Tielaitoksen ylläpitämät museosillat löytyvät valtakunnallisesta RKYluettelosta ja Struven ketjun Suomeenkin levittäytyvät kolmiomittaustornit jopa Unescon Maailmanperintöluettelosta, mutta kansallisen identiteetin rakennusaineksiksi, Eiffel-tornin, USA:n Hoover-padon ja Golden Gate -sillan tai Skotlannin Forth-vuonon sillan tavoin, niillä on vielä matkaa. On vaikea kuvitella, että taidehistoriassa osana tämän päivän humanistista tutkimusta edellytettäisiin aihevalinnassa kansallista luonnetta. Ajankohtaiselta tutkimukselta voi sen sijaan edellyttää kansallistuntoisuuksien ja nationalismien esiin tuomista. Kansallissosialismin ajan Saksassa esimerkiksi pyrittiin varmistamaan Kolmannen valtakunnan tuleminen paitsi rotuoppien avulla myös ylevillä maisemilla. Näitä saksalaiset automatkailijat ohjattiin ihailemaan tarkoitukseen rakennetuilla moottoriteillä. ${ }^{50}$ Suomalaiset tiealan asiantuntijat raportoivat Führerin saavutuksista paikan päältä. ${ }^{51}$

Taidehistoriassa, kuten muillakin tieteenaloilla, tutkimuskohteen määrittelyyn ja rajaukseen sisältyy polkuriippuvuutta, jossa aikaisemmat valinnat kertautuvat seuraavissa. Valintoja tehdään useassa portaassa: tutkija valitsee kohteensa, aineistonsa ja tutkimusotteensa, yleisesityksen kirjoittaja tai toimittaja sen aihealueet, opettaja johdantokurssin teemat. Yksittäisen tutkijan vapausaste on suurin. Yleisesityksiä ja opetusohjelmia sen sijaan ohjaa usein polkuriippuvuus suhteessa aiemmin tehtyihin ratkaisuihin. Kansallinen konteksti on näissä yleensä annettuna reunaehtona, eikä kaanonien purkamiseen jää juuri mahdollisuutta.

50 Thomas Zeller, Driving Germany: the landscape of the German Autobahn, 1930-1970 (New York: Berghahn Books, 2010).

51 R. Dunckers, "Münchenin tienäyttely. Kolmannen valtakunnan valtava kulttuurinäyttely," Tielehti nro. 3 (1934): 106-109. 
Artikkelissa käsitellyt kaksi taidehistorian tutkimuksen reuna-aluetta toimivat esimerkkeinä siitä, miten taidehistoria edelleen rajaa yleisesityksissä ilmenevää ydinaluettaan institutionalisoituneiden taiteenalojen ja niihin kytkeytyvien toimijaryhmien pohjalta ylläpitäen näin perinteisiä taiteen hierarkioita. Emme halua kritisoida yksittäisiä tutkijoita tehdyistä rajauksista tai valinnoista, mutta pidämme tärkeänä sitä, että myös taidehistoriallisen perustutkimuksen hyödyntämisessä valinnat ja rajaukset tehdään mahdollisuuksien mukaan avoimesti ja reflektoidusti. Tarpeen tulleen näitä voidaan myös haastaa.
Maunu Häyrynen on taidehistorioitsija, joka on väitellyt Helsingin kaupunkipuistojen historiasta ja tutkinut myös $\mathrm{mm}$. Suomen kansallisen maisemakuvaston rakentumista. Hän toimii maisemantutkimuksen professorina Turun yliopistosta.

Linda Leskinen on tohtorikoulutettava Helsingin yliopiston taidehistorian oppiaineessa.

\section{Kirjallisuus}

Asola, Ismo. Vesitorni, yhdyskuntien maamerkki. Helsinki: Suomen Rakennusinsinöörien Liitto, 2003. Bal, Mieke. "The Commitment to Look." Journal of Visual Culture 4, no. 2 (2005): 145-162. Hurme, Riitta et al., toim. Betoni Suomessa 1860-1960. Helsinki: Suomen Betoniyhdistys, 1991.

Ching, Francis D. K., Jarzombek, Mark M. \& Prakash, Vikramaditya. A Global History of Architecture, $3^{\text {rd }}$ ed. Hoboken: Wiley, 2017.

Conway, Hazel \& Roenisch, Rowan. Understanding Architecture. An Introduction to Architecture and Architectural History, $2^{\text {nd }}$ ed. New York \& London: Routledge, 2005.

Donner, Julia. Kasvitarhasta puutarhakotiin. Naiset kotipuutarhan tekijöinä Suomessa 1870-1930. Helsinki: Helsingin yliopisto, 2015.

Dunckers, R. "Münchenin tienäyttely. Kolmannen valtakunnan valtava kulttuurinäyttely." Tielehti nro. 3, 1934: 106-109.

Eglash, Ron et al. "Technology as material culture." In Handbook of Material Culture, edited by Christopher Tilley et al., 329-340. London: Sage, 2006.

Elkins, James. Stories of Art. New York \& London: Routledge, 2002.

Foucault, Michel. "What is an Author?." in Michel Foucault: Aesthetics, Method and Epistemology, edited by James Faubion, 205-222. New York: The New Press, 1969 [1998].

Giedion, Sigfried. Space, Time and Architecture. The growth of a new tradition. Cambridge: Harward University Press, 1941 [1952]. 
Gothein, Marie Luise. Geschichte der Gartenkunst I-II. Jena: Eugen Diederichs Verlag, 1914.

Gürel, Meltem \& Anthony, Kathryn H. "The Canon and the Void: Gender, Race, and Architectural History Texts." Journal of Architectural Education 59, no. 3 (2006): 66-76.

Honour, Hugh \& Fleming, John. A World History of Art, 7th ed. London: Laurence King, 2009.

Fleming, John, Honour, Hugh \& Pevsner, Nikolaus. The Penguin Dictionary of Architecture London: Penguin, 1991.

Hautamäki, Ranja. Kartanot kaupungissa. Helsingin kartanoympäristöjen kaupunkimaistuminen, säilyttäminen ja yhteensovittaminen kaupunkirakenteeseen. Espoo: Aalto-yliopisto, 2016.

Herranen, Timo. Hevosomnibusseista metroon. Vuosisata Helsingin joukkoliikennettä. Helsinki: Helsingin kaupungin liikennelaitos, 1988.

Hietala, Marjatta. Services and Urbanization at the Turn of the Century. The Diffusion of Innovations. Helsinki: Suomen historiallinen seura, 1987.

Häyrynen, Maunu. "Betonin käyttö sillan- ja vesirakennuksessa 1800-luvun lopulta 1960-luvun alkuun." Teoksessa Betoni Suomessa 1860-1960, toimittaneet Riitta Hurme et al., 113-178. Helsinki: Suomen Betoniyhdistys, 1991.

Häyrynen, Maunu. "Mårten Gabriel Stenius." Kansallisbiografia, toimittanut Matti Klinge. Helsinki: Suomalaisen Kirjallisuuden Seura, 2003.

Häyrynen, Maunu. "Suomalainen puutarha." Teoksessa Hortus Fennicus. Suomen puutarhataide, toimittaneet Maunu Häyrynen et.al., 10-31. Helsinki: Viherympäristöliitto, 2001.

Häyrynen, Maunu. Maisemapuistosta reformipuistoon. Helsingin kaupunkipuistot ja puistopolitiikka 1880-luvulta 1930-luvulle. Helsinki: Helsinki-Seura, 1994.

Jaatinen, Martti. Tie suomalaisessa maisemassa. Porvoo: WSOY, 1967.

Jaatinen, Martti, toim. Suomi rakentaa: nykyarkkitehtuurin näyttely Taidehallissa 3. 23.3.-15.4.1963. Helsinki: Suomen Rakennustaiteen museo, 1963.

Jellicoe, Geoffrey \& Jellicoe, Susan. The Landscape of Man. Shaping the Environment from Prehistory to the Present Day. London: Thames \& Hudson, 1995.

Kaipia, Jouni \& Putkonen, Lauri. A Guide to Finnish Architecture. Helsinki: Otava, 1997.

Knapas, Rainer. Monrepos. Ranskalaisen kulttuurin pohjoinen keidas. Helsinki: Suomalaisen Kirjallisuuden Seura, 2008.

Kopomaa, Timo. Kaupunkipuiston käytöt: elämää Helsingin puistoissa ja ulkoilualueilla. Helsinki: Helsingin kaupungin tietokeskus, 1995.

Kraft, Selma."Interdisciplinarity and the Canon of Art History." Issues in Integrative Studies 7 (1989): $57-71$.

Lahtinen, Rauno \& Laaksonen, Hannu. Kävelyllä puistojen Turussa. Turku: Turkuseura, 2008.

Langfeld, Gregor. "The canon in art history: concepts and approaches." Journal of Art Historiography 19, no. 12 (2018): 1-18.

Lefebvre, Henri. The Production of Space. Oxford: Blackwell, 1991.

Leskinen, Linda. "Suomen kaunein tie. Tarvon moottoritie ja uuden kaupunkitilan rakentaminen 19561962 (työnimi)". Väitöstutkimus, Helsingin yliopisto, tulossa. 
Lilius, Henrik. "Miljöötutkimuksen menetelmistä ja tavoitteista." Teoksessa Taidehistoria ja ympäristöntutkimus, toimittaneet Leena Arkio \& Kalevi Pöykkö, 9-18. Helsinki: Gaudeamus, 1975. Locher, Hubert. "The idea of the canon and canon formation in art history." In Art History and Visual Studies in Europe: Transnational Discourses and National Frameworks, edited by M. Rampley et al., 29-40. Amsterdam: Brill, 2012.

Lukkarinen, Ville. "Taiteen tarina." Teoksessa Katseen rajat. Taidehistorian metodologiaa, toimittaneet Arja Elovirta \& Ville Lukkarinen, 17-58. Helsinki: Helsingin yliopisto, 1998.

Lönnqvist, Bo. Vanhoja kartanoita Helsingin seudulla: kulttuurihistoriallisia ajankuvia. Espoo: Schildts, 1995.

Melville, Stephen. "'Theory', Discipline, and Institution." In Art History, Aesthetics, Visual Studies. Edited by Michael Ann Holly \& Keith Moxey, 203-214. New Haven, Conn.: Yale University Press, 2002.

Merivuori, Tuula-Maria. "Bengt Schalin ja vuosisadan alun muotopuutarha." Teoksessa Hortus Fennicus. Suomen puutarhataide, toimittaneet Maunu Häyrynen et al., 256-269. Helsinki: Viherympäristöliitto, 2001.

Meurman, Otto I. "Tie ja maisema." Tielehti nro. 1, 1949: 2-5.

Mukerji, Chandra. "The landscape garden as material culture: Lessons from France." In The Oxford Handbook of Material Culture Studies, edited by Dan Hicks \& Mary Beaudry. Oxford: Oxford University Press, 2010. DOI: 10.1093/oxfordhb/9780199218714.013.0024.

Mäkinen, Anne. Suomen valkoinen sotilasarkkitehtuuri 1926-1939. Helsinki: Suomalaisen Kirjallisuuden Seura, 2000.

Nikula, Riitta. Suomen arkkitehtuurin ääriviivat. Helsinki: Otava, 2005.

Nikula, Riitta. "Kaupunkitutkimus." Teoksessa Katseen rajat, taidehistorian metodologiaa, toimittaneet Arja Elovirta \& Ville Lukkarinen, 177-182. Helsinki: Helsingin yliopisto, 1998.

Nikula, Riitta. "Rakennustaiteen 1920- ja 1930-luku." Teoksessa ARS Suomen taide 5, toimittaneet Salme Sarajas-Korte et al., 86-157. Helsinki: Otava, 1990.

Nikula, Riitta. "Bertel Jung modernin kaupunkisuunnittelun käynnistäjänä." Teoksessa Bertel Jung, suurkaupungin hahmottaja, toimittaneet Mikael Sundman \& Mona Schalin, 9-41. Helsinki: Kaupunkisuunnitteluvirasto, 1988.

Piponius, Gunnar. "Tarvon - Gumbölen autotie." Tielehti nro. 4 (1957): 39-45. Preziosi, Donald. "Art History: Making the Visible Legible." In The Art of Art History: A Critical Anthology, edited by Donald Preziosi, 7-11. Oxford: Oxford University Press, 1998. Preziosi, Donald. Rethinking Art History. Meditations on a Coy Science. New Haven \& London: Yale University Press, 1989.

Putkonen, Lauri. "Betonin käyttö talonrakennuksessa 1800-luvun lopulta 1930-luvulle." Teoksessa Betoni Suomessa 1860-1960, toimittaneet Riitta Hurme et al., 31-76. Helsinki: Suomen Betoniyhdistys, 1991.

Ruoff, Eeva. "Paul Olsson." Kansallisbiografia, toimittanut Matti Klinge. Helsinki: Suomalaisen Kirjallisuuden Seura, 2003.

Saarikangas, Kirsi. Asumisen muodonmuutoksia. Puhtauden estetiikka ja sukupuoli modernissa arkkitehtuurissa. Helsinki: Suomalaisen Kirjallisuuden Seura, 2002.

Saarikangas, Kirsi. "Tilan tekijät." Teoksessa Katseen rajat. Taidehistorian metodologiaa, toimittaneet Arja Elovirta \& Ville Lukkarinen, 183-205. Helsinki: Helsingin yliopisto, 1998. 
Saarikangas, Kirsi, toim. Kuvasta tilaan. Taidehistoria tänään. Tampere: Vastapaino, 1999.

Santala, Susanna. Laboratory for a New Architecture: The Airport Terminal, Eero Saarinen and the Historiography of Modern Architecture. Helsinki: Helsingin yliopisto, 2015.

Soiri-Snellman, Helena. "Turun Vartiovuorenpuisto." Teoksessa Hortus Fennicus. Suomen puutarhataide, toimittaneet Maunu Häyrynen et al., 190-197. Helsinki: Viherympäristöliitto, 2001.

"Suomi rakentaa III. Jälkipuinti." Arkkitehti nro. 4, 1963: 25-28.

Suominen-Kokkonen, Renja. Rakennusmestariarkkitehtuuri Suomessa ja sen taustalla ollut koulutus. Rakennusmestarit ja teollisuuskoulujen huonerakennusosastojen koulutus 1885-1911. Helsinki: Helsingin yliopisto, 1989.

Sørensen, C. Th. Europas havekunst fra Alhambra til Liselund. København: G. E. C. Guds forlag, 1959.

Taylor, Patrick, ed. The Oxford Companion to the Garden. Oxford: Oxford University Press, 2006.

Thacker, Christopher. The History of Gardens. London: Croom Helm, 1979.

"Tie Suomen maisemassa." Tielehti nro 3, 1966: 19.

"Tulevaisuuden tie." Uuden Suomen Kuvalehti nro 6-7, 1957.

Valkeapää, Leena. Pitäjänkirkosta kansallismonumentiksi. Suomen keskiaikaisten kivikirkkojen restaurointi ja sen tausta vuosina 1870-1920. Helsinki: Suomen Muinaismuistoyhdistys, 2000.

Viljo, Eeva Maija. Theodor Höijer. En arkitekt under den moderna storstadsarkitekturens genombrottstid i Finland från 1870 till sekelskiftet. Helsinki: Suomen Muinaismuistoyhdistys, 1985.

Vänskä, Annamari. Vikuroivia vilkaisuja. Ruumis, sukupuoli, seksuaalisuus ja visuaalisen kulttuurin tutkimus. Helsinki: Taidehistorian Seura, 2006.

Wäre, Ritva. "Arkkitehtuuri vuosisadan vaihteessa." Teoksessa: ARS Suomen taide 4, toimittaneet Salme Sarajas-Korte et al., 112-169. Helsinki: Otava, 1989.

Zeller, Thomas. Driving Germany: the landscape of the German Autobahn, 1930-1970. New York: Berghahn Books, 2010. 